\title{
COLUMN BIOREACTOR USE FOR OPTIMIZATION OF PECTINASE PRODUCTION IN SOLID SUBSTRATE CULTIVATION
}

\author{
Giani Andrea Linde*1; Glênio Magagnin ${ }^{2}$; Jorge Alberto Vieira Costa²; Telma Elita Bertolin ${ }^{3}$; Nelson Barros Colauto \\ ${ }^{1}$ Universidade Paranaense, Laboratório de Biologia Molecular, Umuarama, PR, Brasil; ${ }^{2}$ Universidade Federal do Rio Grande, \\ Departamento de Química, Laboratório de Engenharia Bioquímica, Rio Grande, RS, Brasil; ${ }^{3}$ Universidade de Passo Fundo, \\ Instituto de Ciências Biológicas, Laboratório de Tecnologia das Fermentações, Passo Fundo, RS, Brasil.
}

Submitted: October 19, 2006; Returned to authors for corrections: January 04, 2006;Approved: April 09, 2007.

\begin{abstract}
This study aimed to determine the influence of process variables and production, of polygalacturonase (PG) and polymetylgalacturonase (PMG) by solid substrate cultivation using a fixed bed column bioreactor. A fractional factorial design (FFD) was used to study the effect of the following variables: microorganism (Aspergillus oryzae and Aspergillus niger), substratum (wheat bran and defatted rice bran), aeration (40 and $60 \mathrm{ml} \mathrm{h}^{-1} \mathrm{~g}^{-1}$ ), pectin (5 and $10 \mathrm{~g} \mathrm{~g}^{-1}$ ) and nitrogen (urea and ammonium sulfate). Microorganism, aeration and initial pectin were identified in FFD as significant variables $(\mathrm{p}<0.05)$ on $\mathrm{PG}$ production. A central composed design to optimize PG and PMG productions indicated that Aspergillus niger presents higher PG production; substratum and nitrogen do not affect PG production; the aeration rate affects positively the production of PG and negatively the production of PMG and the initial pectin concentration affects positively both PG and PMG production. The optimal point of aeration and initial pectin concentration for PG production are $66.13 \mathrm{ml}$ $\mathrm{h}^{-1} \mathrm{~g}^{-1}$ and $12.8 \mathrm{~g} \mathrm{~g}^{-1}$, respectively and for PMG production are $40 \mathrm{ml} \mathrm{h}^{-1} \mathrm{~g}^{-1}$ and $15.0 \mathrm{~g} \mathrm{~g}^{-1}$, respectively.
\end{abstract}

Key words: Solid state fermentation, agro-industrial residues, pectinase.

\section{INTRODUCTION}

Solid substrate cultivation (SSC) is a process for bioactive composite production that presents several advantages in enzyme production for industrial applications such as lower attack by proteases and higher enzymatic thermo stability $(12,14,20,25)$. For enzyme production using SSC, a fixed column bioreactor is considered the ideal one for small scale studies, because it is inexpensive and easy to use in the control of the process variables $(7,19)$.

Pectinases are enzymatic biocomposites widely used in the industries because of their capacity to degrade pectic substances as fiber deguming (4), citric fruit peeling, industrial residues from the process of coffee, cocoa, tabacco, tea (14), wine clarification, juice extraction, fruit and pectin hydrolyses (10). Pectinase synthesis occurs in many microbial groups, however, for the industrial pectinase production, fungi are the most used group due to their high enzymatic excretion capacity (23). Pectinolytic enzyme synthesis is highly influenced by substratum, particularly, carbon and nitrogen sources (6), presence of pectin (24) and temperature (3). Santos et al. (22) reported that the aeration rate affects the substratum temperature and recommend controlling it to avoid overheating and enzyme denaturation during SSC.

Pectinase production has been already studied but there are no studies about the use of agroindustrial residues and industrial polysaccharides from Brazil to optimize polygalacturonase (PG) and polymetylgalacturonase (PMG) production by solid substrate cultivation. This study aimed to determine the influence of process variables such as microorganisms, substrate, aeration rates, initial pectin concentrations and nitrogen sources on the production of polygalacturonase (PG) and

*Corresponding Author. Mailing address: UNIPAR - Laboratório de Biologia Molecular - Praça Mascarenhas de Moraes s/n - Campus Sede $87502-210$ Umuarama, PR - Brasil. E-mail: gianilinde@unipar.br 
polymetylgalacturonase (PMG) by solid substrate cultivation using a fixed bed column bioreactor.

\section{MATERIALS AND METHODS}

\section{Inocula preparation}

Aspergillus niger and Aspergillus oryzae were kept on potato dextrose agar (PDA) at $4^{\circ} \mathrm{C}$. The inocula were made after the growth of these microorganisms on PDA during 7 days at $30^{\circ} \mathrm{C}$, until the complete fungus sporulation. The spores were suspended in sterilized aqueous solution $\left(121^{\circ} \mathrm{C}\right.$ for $\left.15 \mathrm{~min}\right)$ with $0.2 \%$ Tween- 80 detergent. Spore concentration was determined by direct count in a Neubauer cell-counter chamber, according to Hasan et al. (9).

\section{Experimental design}

A fractional factorial design $2^{5-1}$ (FFD) was used to identify variables that affect $(\mathrm{p}<0.05) \mathrm{PG}$ production in solid substrate cultivation. The variables studied in the FFD were aeration in volume of air per time and mass of dried medium $\left(\mathrm{ml} \mathrm{h}^{-1} \mathrm{~g}^{-1}\right)$, concentration of pectin in mass of pectin added per mass of dried medium $\left(\mathrm{g} \mathrm{g}^{-1}\right)$, sources of nitrogen added to obtain 0.03 mol of nitrogen per mass of dried medium $\left(\mathrm{mol} \mathrm{g}^{-1}\right)$, microorganism (Aspergillus niger or Aspergillus oryzae), and bran (wheat or rice). The runs, variables and coded values studied in FFD are shown in Table 1.
According to the results from the FFD, a central composite design (CCD) was performed to optimize the culture conditions to produce PG and PMG. The runs, variables and coded values studied in the central composite design are shown in Table 2. All experiments were performed in triplicate.

\section{Culture media and bioreactor}

Culture media to FFD and CCD were prepared mixing $150 \mathrm{~g}$ of wheat or rice brans with commercial orange pectin (Braspectina ${ }^{\circledR}$ with high degree of metoxylation) as shown in Table 1 for FFD and in Table 2 for CCD. The moisture in culture media was adjusted to $50 \%$ and $0.018 \mathrm{~g}$ of $\mathrm{KH}_{2} \mathrm{PO}_{4}$ and $0.09 \mathrm{~g}$ of $\mathrm{MgSO}_{4}$ were added per gram of dried medium. The sterilization of the media was carried out at $121^{\circ} \mathrm{C}$ for $15 \mathrm{~min}$. The $\mathrm{pH}$ was adjusted to 3.5 with $\mathrm{HCl}(2 \mathrm{~N})$ and then nitrogen solutions were added to obtain $0.03 \mathrm{~mol}$ of nitrogen per gram of dried medium. All solutions were sterilized by filtration $(0.22 \mu \mathrm{m}$ pore size filter). The culture media were inoculated to concentration of $4 \times 10^{6}$ spores per gram of dried medium. Each inoculated culture medium was transferred aseptically to a fixed bed column bioreactor. The bioreactor consisted of a glass tube with internal diameter of $50 \mathrm{~mm}$ and length of $300 \mathrm{~mm}$, water flow jacketed with another glass tube ( $5 \mathrm{~mm}$ in between glass tubes) to keep the outside temperature of the bioreactor at $30^{\circ} \mathrm{C}$. The inlet of water saturated air inside of the bioreactor was controlled by a system described by Hasan et al. (9), shown at Fig. 1.

Table 1. Runs, variables and coded values studied in the $2^{5-1}$ fractional factorial design (FFD).

\begin{tabular}{|c|c|c|c|c|c|c|c|c|c|c|}
\hline Run & \multicolumn{10}{|c|}{ Variables value } \\
\hline 01 & Aspergillus oryzae & -1 & Wheat & -1 & 40 & -1 & 05 & -1 & Ammonium sulfate & +1 \\
\hline 02 & Aspergillus niger & +1 & Wheat & -1 & 40 & -1 & 05 & -1 & Urea & -1 \\
\hline 05 & Aspergillus oryzae & -1 & Wheat & -1 & 60 & +1 & 05 & -1 & Urea & -1 \\
\hline 06 & Aspergillus niger & +1 & Wheat & -1 & 60 & +1 & 05 & -1 & Ammonium sulfate & +1 \\
\hline 07 & Aspergillus oryzae & -1 & Rice & +1 & 60 & +1 & 05 & -1 & Ammonium sulfate & +1 \\
\hline 08 & Aspergillus niger & +1 & Rice & +1 & 60 & +1 & 05 & -1 & Urea & -1 \\
\hline 09 & Aspergillus oryzae & -1 & Wheat & -1 & 40 & -1 & 10 & +1 & Urea & -1 \\
\hline 10 & Aspergillus niger & +1 & Wheat & -1 & 40 & -1 & 10 & +1 & Ammonium sulfate & +1 \\
\hline 14 & Aspergillus niger & +1 & Wheat & -1 & 60 & +1 & 10 & +1 & Urea & -1 \\
\hline 15 & Aspergillus oryzae & -1 & Rice & +1 & 60 & +1 & 10 & +1 & Urea & -1 \\
\hline 16 & Aspergillus niger & +1 & Rice & +1 & 60 & +1 & 10 & +1 & Ammonium sulfate & +1 \\
\hline
\end{tabular}

Aeration was volume of air per time and mass of dried medium $\left(\mathrm{ml} \mathrm{h}^{-1} \mathrm{~g}^{-1}\right)$; pectin was mass of pectin per mass of dried medium $\left(\mathrm{g} \mathrm{g}^{-1}\right)$; nitrogen was added to obtain $0.03 \mathrm{~mol}$ of nitrogen per mass of dried medium $\left(\mathrm{mol} \mathrm{g}^{-1}\right)$. 
Table 2. Runs, variables and coded values studied in the $2^{2}$ central composed design (CCD).

\begin{tabular}{ccccc}
\hline \multicolumn{5}{c}{ Variables values } \\
\hline Run & $\begin{array}{c}\text { Aeration } \\
\text { coded value }\end{array}$ & Aeration & $\begin{array}{c}\text { Pectin } \\
\text { coded value }\end{array}$ & Pectin \\
\hline 01 & 45 & -1 & 6.5 & -1 \\
02 & 75 & +1 & 6.5 & -1 \\
03 & 45 & -1 & 13.5 & +1 \\
04 & 75 & +1 & 13.5 & +1 \\
05 & 60 & 0 & 10.0 & 0 \\
06 & 60 & 0 & 10.0 & 0 \\
07 & 40 & $-\alpha$ & 10.0 & 0 \\
08 & 80 & $+\alpha$ & 10.0 & 0 \\
09 & 60 & 0 & 5.0 & $-\alpha$ \\
10 & 60 & 0 & 15.0 & $+\alpha$ \\
11 & 60 & 0 & 10.0 & 0 \\
12 & 60 & 0 & 10.0 & 0 \\
\hline
\end{tabular}

Aeration is volume of air per time and mass of dried medium $\left(\mathrm{ml} \mathrm{h}^{-1} \mathrm{~g}^{-1}\right)$; Pectin is in mass of pectin per mass of dried medium $\left(\mathrm{g} \mathrm{g}^{-1}\right)$. Constant culture conditions: microorganism (Aspergillus niger), bran (defatted rice bran) and nitrogen source (ammonium sulfate).

\section{Enzymatic activity and extraction}

The raw extract was made with $5 \mathrm{~g}$ of fermented culture medium mixed (1:10) with acetate buffer solution ( $\mathrm{pH} 4.4)$. The mixture was shaken at $100 \mathrm{rpm}$ for $30 \mathrm{~min}$ at $35^{\circ} \mathrm{C}$ and then filtrated. The raw extract was used to determine free reducing sugars (FRS) and enzymatic activities of PG and PMG, according to Castilho et al. (5).

To determine FRS a 3,5-dinitrosalicylic acid method was used with glucose as standard (15). The FRS were expressed as mass of glucose per mass of dried medium $\left(\mathrm{mg} \mathrm{g}^{-1}\right)$. Dry mass was determined based on the principle of drying until constant weight at $105^{\circ} \mathrm{C}$, according to $\mathrm{AOAC}(1)$.

For PG activity $5 \mathrm{ml}$ of polygalacturonic acid $(0.5 \%$ prepared daily in $\mathrm{pH} 5.0$ with phosphate-citric acid buffer) was added to a test tube with $1 \mathrm{ml}$ of raw enzymatic extract (diluted 1:50). The enzymatic reaction occurred during $60 \mathrm{~min}$ at $37^{\circ} \mathrm{C}$. The released D-galacturonic acid was quantified as reducing sugar using 3,5-dinitrosalicylic acid at $540 \mathrm{~nm}$ and D-galacturonic acid as standard (15). An enzymatic activity unit (U) was defined as the amount of enzyme that releases one $\mu \mathrm{mol}$ of galacturonic acid per min at $37^{\circ} \mathrm{C}(12,14)$. PG production was expressed as enzymatic activity unit per mass of dried medium $\left(\mathrm{U} \mathrm{g}^{-1}\right)$.

For the measurement of enzymatic activity of PMG, $2 \mathrm{ml}$ of raw enzyme extract (diluted 1:25) was mixed to $8 \mathrm{ml}$ of orange pectin from Sigma at $0.63 \%$ in acetate buffer, $\mathrm{pH} 4.0$. The solution was kept in water bath at $30^{\circ} \mathrm{C}$ for $30 \mathrm{~min}$. The viscosity reduction

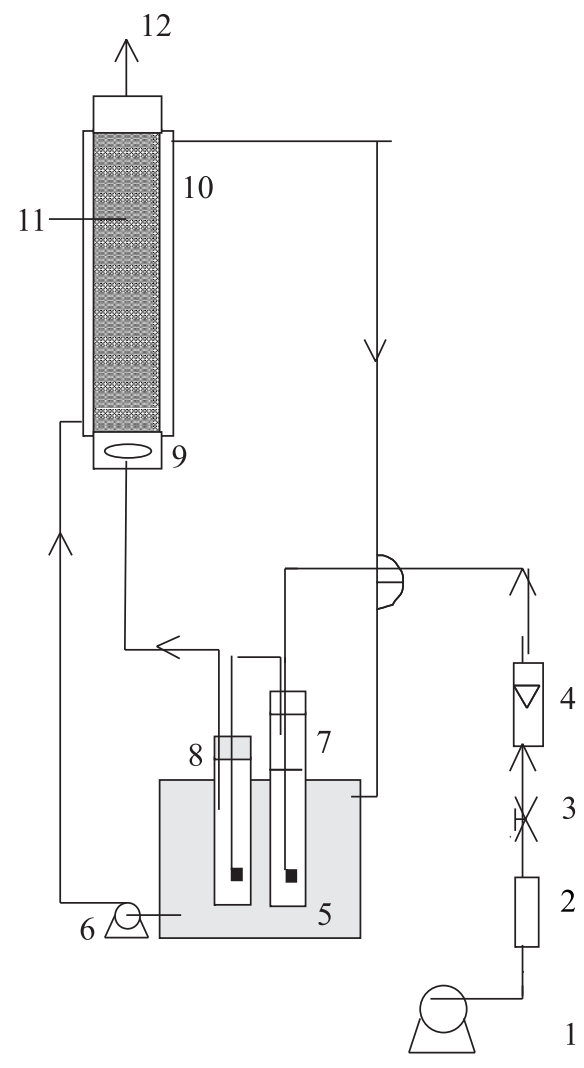

Figure 1. Experimental device used for solid substrate cultivation (1) air injection, (2) air filter (glass wood), (3) air flow control, (4) flow meter, (5) water bath, (6) water pump, (7) humidifier, (8) drop eliminator, (9) air distributor, (10) water flow jacket, (11) cultivation bed, (12) gas outlet.

of the mixture was measured with a Brookfield rotational viscosimeter. One enzymatic unit was defined as the amount of enzyme that reduces the initial viscosity of the solution to $50 \%$ in 30 min (12). PMG production was expressed as enzymatic activity unit per mass of dried medium $\left(\mathrm{U} \mathrm{g}^{-1}\right)$.

\section{RESULTS AND DISCUSSION}

\section{Identification of variables that affected $P G$ production in fractional factorial design (FFD)}

According to the FFD experimental conditions (Table 1) it was calculated the effects of the variables on PG production presented in Table 3. The effects show how much each variable affected PG production. The variable "microorganism" presented higher effect on PG production. At $60 \mathrm{~h}$ of cultivation, the Aspergillus niger increased PG production on $368.9 \mathrm{U} \mathrm{g}^{-1}$ (Table 3), which represents a 46.1\%, comparing with Aspergillus oryzae. This result is similar to Baracat et al. (4) and Castilho et al. (5) that reported high pectinase activities produced by 
Table 3. Effects as enzymatic activity units per mass of dried medium $\left(\mathrm{U} \mathrm{g}^{-1}\right)$ of studied variables in fractional factorial design $2^{5-1}$ (FFD) on polygalacturonase (PG) activity along the cultivation time.

\begin{tabular}{lccccc}
\hline \multirow{2}{*}{ Variable } & \multicolumn{5}{c}{ Cultivation Time (h) } \\
\cline { 2 - 6 } & 36 & 48 & 60 & 72 & 96 \\
\hline Microorganism & $154.8^{*}$ & $283.2^{*}$ & $368.9^{*}$ & $362.9^{*}$ & $217.2^{*}$ \\
Bran & 2.4 & 11.1 & 32.7 & 48.0 & 38.9 \\
Aeration & 14.2 & $69.8^{*}$ & $153.5^{*}$ & $190.9^{*}$ & $85.4^{*}$ \\
Pectin & 45.1 & $100.3^{*}$ & $140.6^{*}$ & $116.6^{*}$ & 29.8 \\
Nitrogen & 13.3 & 20.3 & 36.0 & 38.0 & 20.3 \\
\hline
\end{tabular}

$* \mathrm{p}<0.05$.

Aspergillus niger strains. The A. niger has been used as producer of pectinases $(18,26)$. Patil and Dayanand (21) used a multi-step screening technique based on coefficient of pectolysis and capability of pectinase production to isolate microorganisms with high potential to produce pectinases. They found A. niger as the best producer among the tested microorganisms. Besides that enzymatic extracts of A. niger have been used safely in food (10) and feed (17) industry and another applications as model to study the interaction between protein and carbohydrate (11) and to promote plant protection (2). Thus, the use of A. niger was chosen to the next experimental phase, and one variable was ruled out.

Pectin addition to the culture media induced $\mathrm{PG}$ production $(\mathrm{p}<0.05)$. At $60 \mathrm{~h}$ of cultivation, an increase on initial pectin concentration from 5 to $10 \mathrm{~g} \mathrm{~g}^{-1}$ resulted in increases of PG production on $140.6 \mathrm{U} \mathrm{g}^{-1}$ (Table 3). The pectinase production induced by pectin's concentration in the substrate, found in this study, was similar to that reported by Kashyap et al. (10) with Bacillus sp and by Fontana et al. (8) with A. niger. Fontana et al. (8) reported that pectin can be used by A. niger as a growth substrate besides its role as an inducer. These results agree with Maldonado and Strasser de Saad (13) that verified mycelial growth and pectinase production by $A$. niger using pectin as a sole carbon source. Thus, pectin was selected to broaden the study range in CCD.

The aeration affected $(\mathrm{p}<0.05)$ the $\mathrm{PG}$ production. At $60 \mathrm{~h}$ of cultivation an increase on aeration from 40 to $60 \mathrm{ml} \mathrm{h}^{-1} \mathrm{~g}^{-1}$ increased PG production on $153.5 \mathrm{U} \mathrm{g}^{-1}$ (Table 3). Increases in aeration rate decreases the temperature of the culture medium and consequently reduces the enzymatic denaturation $(16,22)$. It could explain why the variable aeration affected significantly the $\mathrm{PG}$ production. Thus, aeration was selected to broaden the study range in $\mathrm{CCD}$ to determine the optimal range for pectinase production.

The variables "nitrogen" and "bran" presented positive nonsignificant effects ( $p>0.05$ ) on PG production (Table 3 ). However, the PG activity values obtained with rice bran and ammonium sulfate were slightly higher than the ones with wheat bran and urea. Therefore, defatted rice bran and ammonium sulfate were used as cultivation media in the next experimental phase in CCD. For CCD development the following conditions were used as culture conditions: microorganism (A. niger), bran (defatted rice bran) and nitrogen (ammonium sulfate). Aeration and pectin were selected to broaden the study range in CCD and to optimize values for $\mathrm{PG}$ and $\mathrm{PMG}$ activities.

\section{Pectinase production optimization through central composite design (CCD)}

According to the CCD experimental conditions (Table 2) it was calculated the effects of the variables on PG and PMG productions presented in Table 4 and 5. The highest value obtained in CCD for PG production was $1829 \mathrm{U} \mathrm{g}^{-1}$ at $48 \mathrm{~h}$ of cultivation. This result was $228 \%$ superior to the highest value obtained in FFD, which was $800 \mathrm{U} \mathrm{g}^{-1}$ in $60 \mathrm{~h}$. This optimization of the process variables shows a higher value of PG activity in a shorter culture time. The increase of the aeration rate, in any culture time, showed inverse behavior to PG and PMG activities (Tables 4 and 5). At $48 \mathrm{~h}$ of cultivation, the change in the aeration rate from 40 to $80 \mathrm{ml} \mathrm{h}^{-1} \mathrm{~g}^{-1}$ increased the PG production on $323.2 \mathrm{U} \mathrm{g}^{-1}$ (Table 4). The same change in aeration rate, at $48 \mathrm{~h}$ of cultivation, provided a decrease in the PMG production on $52.9 \mathrm{U} \mathrm{g}^{-1}$ (Table 5). However, pectin presented positive effects $(\mathrm{p}<0.05)$ on both PG and PMG activities. The increase of the initial pectin concentration from 5 to $13.5 \mathrm{~g} \mathrm{~g}^{-1}$, at $60 \mathrm{~h}$ of cultivation, increased the PG production on $387.0 \mathrm{U} \mathrm{g}^{-1}$ (Table 4) and the PMG production on $98.4 \mathrm{U} \mathrm{g}^{-1}$ (Table 5). This variation in the initial pectin concentration represented a $122 \%$ increase on PG production and $347 \%$ on PMG production.

Increases in aeration rate decreases the temperature of the culture medium and consequently reduces the enzymatic denaturation $(16,22)$. It explains the $\mathrm{PG}$ production increase, but not the PMG production decrease in this study. It is possible that the PMG activity or/and synthesis are strongly

Table 4. Effects as enzymatic activity units per mass of dried medium $\left(\mathrm{U} \mathrm{g}^{-1}\right)$ of studied variables in the central composite design (CCD) on polygalacturonase (PG) activity along the cultivation time.

\begin{tabular}{cccccc}
\hline \multirow{2}{*}{ Variable } & \multicolumn{5}{c}{ Cultivation Time (h) } \\
\cline { 2 - 6 } & 36 & 48 & 60 & 72 & 96 \\
\hline Aeration & $137.2^{*}$ & $323.2^{*}$ & $214.2^{*}$ & $112.0^{*}$ & $98.3^{*}$ \\
Pectin & $-7.9^{*}$ & $294.3^{*}$ & $387.0^{*}$ & $49.9^{*}$ & $-18.6^{*}$ \\
\hline
\end{tabular}

*p<0.05; Constant culture conditions: microorganism (Aspergillus niger), bran (defatted rice bran) and nitrogen source (ammonium sulfate). 
Table 5. Effects as enzymatic activity units per mass of dried medium $\left(\mathrm{U} \mathrm{g}^{-1}\right)$ of studied variables in the central composite design (CCD) on polymetylgalacturonase (PMG) activity along cultivation time.

\begin{tabular}{cccccc}
\hline \multirow{2}{*}{ Variable } & \multicolumn{5}{c}{ Cultivation Time (h) } \\
\cline { 2 - 6 } & 36 & 48 & 60 & 72 & 96 \\
\hline Aeration & $-31.9^{*}$ & $-52.9^{*}$ & $-58.0^{*}$ & $-39.0^{*}$ & $-22.7^{*}$ \\
Pectin & $45.3^{*}$ & $76.9^{*}$ & $98.4^{*}$ & $92.4^{*}$ & $46.2^{*}$ \\
\hline
\end{tabular}

${ }^{*} \mathrm{p}<0.05$; Constant culture conditions: microorganism (Aspergillus niger), bran (defatted rice bran) and nitrogen source (ammonium sulfate).

affected by the FRS concentration in the culture medium. The results found in this study show that the highest values of PMG activity occurred always when the FRS concentration was lower than $110 \mathrm{mg} \mathrm{g}^{-1}$ (Fig. 2). It means that an increase on aeration rate induces PG activity which increases FRS concentration and consequently inhibits PMG activity. Fontana et al. (8) found similar results working with solid substrate cultivation of A. niger on PG and PMG production. They suggested that the addition of pectin in the substratum could inhibit PMG production by pectin degradation products. Thus, optimal conditions for PG production can inhibit PMG production depending on the FRS concentration in the culture medium.

The highest values for PG activity were obtained at $48 \mathrm{~h}$ of cultivation (Fig. 3). Using a mathematical model which resulted

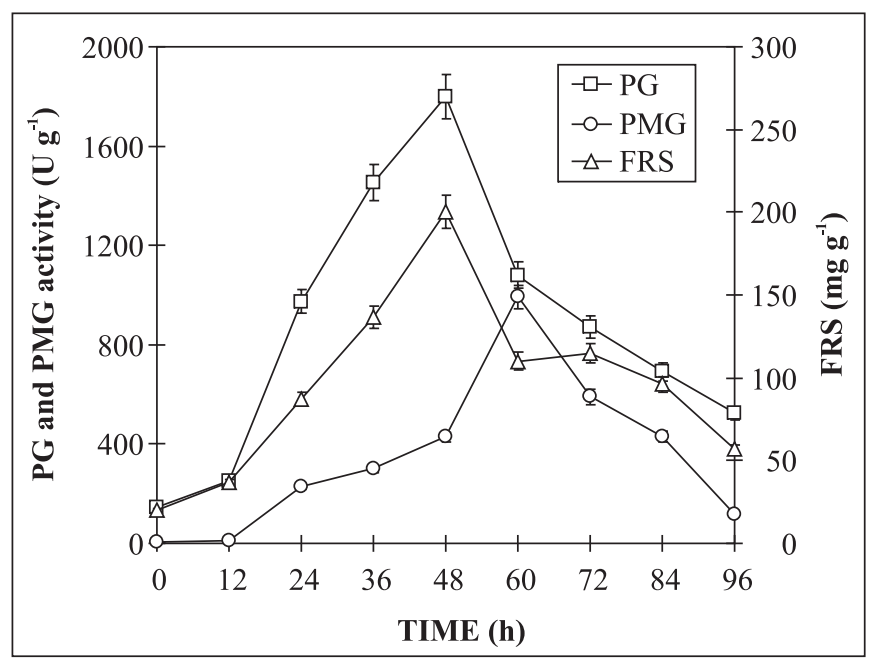

Figure 2. Polygalacturonase (PG), polymetylgalacturonase (PMG) and free reducing sugars (FRS) in relation to cultivation time. Average for four central points of CCD. Constant culture conditions: microorganism (Aspergillus niger), bran (defatted rice bran) and nitrogen source (ammonium sulfate). from CCD, it was possible to calculate the optimal point for PG activity, which was $66.13 \mathrm{ml} \mathrm{h}^{-1} \mathrm{~g}^{-1}$ for aeration and $12.8 \mathrm{~g} \mathrm{~g}^{-1}$ for pectin. When aeration was higher than the optimal point (66.13 $\left.\mathrm{ml} \mathrm{h}^{-1} \mathrm{~g}^{-1}\right)$ PG activity reduction occurred. This behavior is probably related to the increase of the air flow speed inside the bioreactor, which leads to a friction increase and mycelial rupture, decreasing the mycelial growth rate and enzymatic activity. The calculated optimal point of PMG activity, using a mathematical model that resulted from CCD, was $40 \mathrm{ml} \mathrm{h}^{-1} \mathrm{~g}^{-1}$ for aeration and $15.0 \mathrm{~g} \mathrm{~g}^{-1}$ for pectin.

Considering the conditions and methodologies used in this study it was concluded that Aspergillus niger presented higher polygalacturonase activities than Aspergillus oryzae; the substrate and nitrogen source did not affect the polygalacturonase activity; the highest aeration rate affected polygalacturonase activity positively and polymetylgalacturonase, negatively; The highest initial pectin concentration affected positively both polygalacturonase and polymetylgalacturonase activities; the optimal point for the process variables for the polygalacturonase activity was $66.13 \mathrm{ml} \mathrm{h}^{-1} \mathrm{~g}^{-1}$ for aeration and $12.8 \mathrm{~g} \mathrm{~g}^{-1}$ for pectin; the highest values of PMG activity were obtained with $40.0 \mathrm{ml} \mathrm{h}^{-1} \mathrm{~g}^{-1}$ for aeration and $15.0 \mathrm{~g} \mathrm{~g}^{-1}$ for pectin.

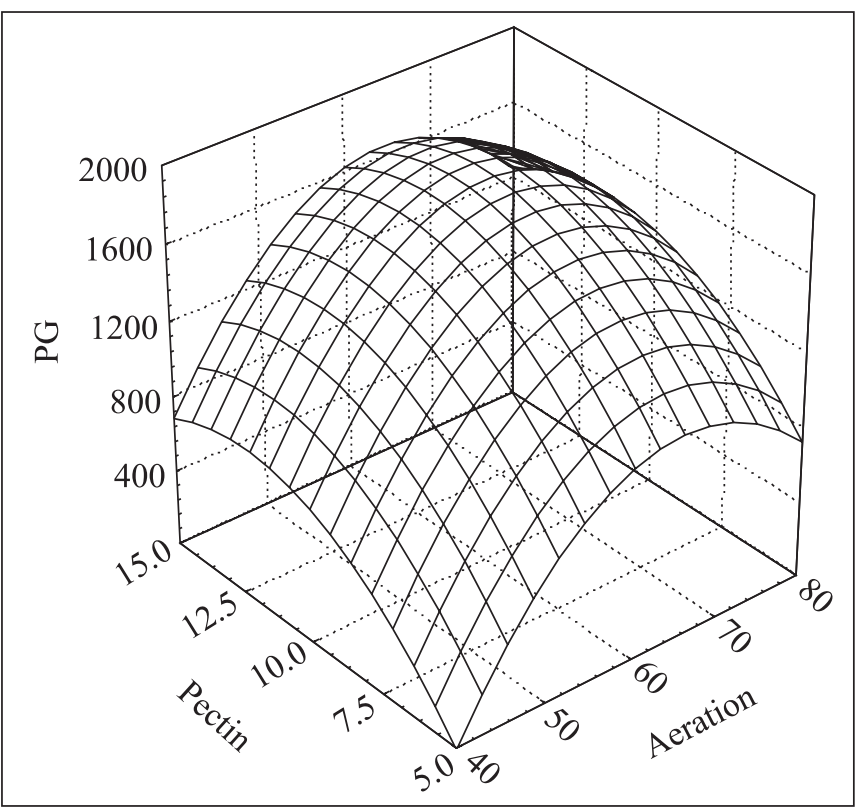

Figure 3. Results of all runs of CCD for polygalacturonase (PG) activity in relation to aeration and initial pectin concentration at $60 \mathrm{~h}$ of cultivation. PG is in unit of enzymatic activity per mass of dried medium $\left(\mathrm{U} \mathrm{g}^{-1}\right)$; Pectin is in mass of pectin per mass of dried medium $\left(\mathrm{g} \mathrm{g}^{-1}\right)$. Constant culture conditions: microorganism (Aspergillus niger), bran (defatted rice bran) and nitrogen source (ammonium sulfate). 


\section{RESUMO}

\section{Uso de bioreator de coluna para otimização da produção de pectinases por cultivo semi-sólido}

O objetivo deste trabalho foi determinar a influência de variáveis de processo na produção das enzimas poligalacturonase (PG) e polimetilgalacturonase (PMG) por cultivo semi-sólido utilizando bioreator de coluna. Um planejamento fatorial fracionário foi utilizado para determinar o efeito das variáveis "microrganismo" (Aspergillus oryzae e Aspergillus niger), "substrato" (farelo de trigo e farelo desengordurado de arroz), "aeração" (40 e $60 \mathrm{ml} \mathrm{h}^{-1} \mathrm{~g}^{-1}$ ), "pectina" (5 e $10 \mathrm{~g} \mathrm{~g}^{-1}$ ) e "nitrogênio" (uréia e sulfato de amônia) para a produção de PG. Microrganismo, aeração e pectina foram significantes $(\mathrm{p}<0,05)$ para a produção de PG. Utilizando-se um planejamento composto central com quadruplicata no ponto central concluiu-se que Aspergillus niger apresenta maior produção de $\mathrm{PG}$, o substrato e a fonte de nitrogênio não afetam $(\mathrm{p}<0,05)$ a produção de $\mathrm{PG}$, a aeração afeta positivamente a produção de $\mathrm{PG}$ e negativamente a de PMG, e a concentração inicial de pectina afeta positivamente a atividade de ambas enzimas. Os pontos ótimos de aeração e de concentração inicial de pectina para a produção de PG são $66,13 \mathrm{ml} \mathrm{h}^{-1} \mathrm{~g}^{-1} \mathrm{e} 12,8 \mathrm{~g}$ $\mathrm{g}^{-1}$, respectivamente, e para a produção de PMG são $40 \mathrm{ml} \mathrm{h}^{-1}$ $\mathrm{g}^{-1}$ e $15,0 \mathrm{~g} \mathrm{~g}^{-1}$, respectivamente.

Palavras-chave: Fermentação semi-sólida, resíduos agroindustriais, pectinase.

\section{REFERENCES}

1. AOAC (1980). Official Methods of Analysis of AOAC International. 13. ed. AOAC, Washington, D.C.

2. Bai, Z.H.; Zhang, H.X.; Qi, H.Y.; Peng, X.W.; Li, B.J. (2004). Pectinase production by Aspergillus niger using wastewater in solidstate fermentation for eliciting plant disease resistance. Bioresour. Technol., 95, 49-52.

3. Bailey, M.J. (1990). Effects of temperature on polygalacturonase production by Aspergillus niger. Enzyme Microb. Technol., 12, 622624.

4. Baracat, M.C.; Valentti, M.C.; Muchovej, J.J.; Araujo, E.F.; Silva, D.O. (1989). Selection of a pectinolitic fungi for deguming of natural fibers. Biotechnol. Lett., 11, 899-702.

5. Castilho, L.; Medronho, R.A.; Alves, T.L.M. (2000). Production and extraction of pectinase obtained by solid state fermentation of agroindustrial residues with Aspergillus niger. Bioresour. Technol., $71,45-50$.

6. De Gregorio, A.; Mandalari, G.; Arena, N.; Nucita, F.; Tripodo, M.M.; Lo Curto R.B. (2002). SCP and crude pectinase production by slurry-state fermentation of lemon pulps. Bioresour. Technol., 83, 89-94.

7. Durand, A. (2003). Bioreactor designs for solid-state fermentation. Biochem. Eng. J., 13, 113-125.
8. Fontana, R.C.; Salvador, S.; Silveira, M.M. (2005). Influence of pectin and glucose on growth and polygalacruronase production by Aspergillus niger in solid-state cultivation. J. Ind. Microbiol. Biotechnol., 32(8), 371-377.

9. Hasan, S.D.M.; Costa, J.A.V.; Sanzo, A.V.L. (1998). Heat transfer simulation of solid state fermentation in a packed-bed bioreactor. Biotechnol. Tech., 12, 787-791.

10. Kashyap, D.R.; Soni, S.K.; Tewari, R. (2003). Enhanced production of pectinase by Bacillus sp. DT7 using solid state fermentation. Bioresour. Technol., 88, 251-254.

11. King, D.; Lumpkin, M.; Bergmann, C.; Orlando, R. (2002). Studying protein-carbohydrate interactions by amide hydrogen/deuterium exchange mass spectrometry. Rapid Commun. Mass Spectrom, 16(16), 1569-1574.

12. Maiorano, A.E.; Okagi, Y. (1995). Determination of enzymatic activity of pectinases from different microorganism. World $J$. Microbiol. Biotechnol., 11, 355-356.

13. Maldonado, M.C.; Strasser de Saad, A.M. (1998). Production of pectinesterase and polygalacturonase by Aspergillus niger in submerged and solid state system. J. Ind. Microbiol. Biotechnol., 20(1), 34-38.

14. Martins, E.S.; Silva, D.; da Silva, R.E.; Gomes, E. (2002). Solid state production of thermostable pectinases from thermophilic Thermoascus aurantiacus. Proc. Biochem., 37, 949-954.

15. Miller, G.L. (1959). Use of dinitrossalicylic acid reagent for determination of reducing sugars. Anal. Chem., 31, 426-428.

16. Mitchell, D.A.; Meien, O.F.V.; Krieger, N. (2003). Recent developments in modeling of solid-state fermentation heat and mass transfer in bioreactors. Biochem. Eng. J., 13, 137-147.

17. Nadeau, E.M.; Buxton, D.R.; Russell, J.R.; Allison, M.J.; Young, J.W. (2000). Enzyme, bacterial inoculant, and formic acid effects on silage composition of orchardgrass and alfalfa. J. Dairy Sci., 83(7), 1487-1502.

18. Nedjma, M.; Hoffmann, N.; Belarbi, A. (2001). Selective and sensitive detection of pectin lyase activity using a colorimetric test: application to the screening of microorganisms possessing pectin lyase activity. Anal. Biochem., 291(2), 290-296.

19. Pandey, A. (1992). Packed-bed column bioreactor for production of enzymes. Enzyme Microbiol. Technol., 14, 486-488.

20. Pandey, A. (2003). Solid-state fermentation. Biochem. Eng. J., 13, $81-84$

21. Patil, S.R.; Dayanand, A. (2006). Optimization of process for the production of fungal pectinases from deseeded sunflower head in submerged and solid-state conditions. Bioresour. Technol., 97(18), 2340-2344

22. Santos, M.M.; Rosa, A.S.; Dal'Boit, S.; Mitchell, D.; Krieger, N. (2004). Thermal denaturation: is solid-state fermentation really a good technology for the production of enzymes? Bioresour. Technol., 94, 261-268.

23. Solis, S.; Flores, M.E.; Huitron, C. (1990). Isolation of endopolygalacturonase hyperproducing mutants of Aspergillus sp.CH-Y-1043. Biotechnol. Lett., 12, 751-756.

24. Solis-Pereira, S.; Favela-Torres, E.; Viniegra-González, G.; GutiérrezRojas, M. (1993). Effects of different carbon sources on the synthesis of pectinase by Aspergillus niger in submerged and solid state fermentation. Appl. Microbiol. Biotechnol., 39, 36-41.

25. Viniegra-González, G.; Favela-Torres, E.; Aguiar, C.N.; RómeroGomez, J.; Diaz-Godínez, G.; Augur, C. (2003). Advantages of fungal enzyme production in solid state over liquid fermentation systems. Biochem. Eng. J., 13, 157-167.

26. Wang, X.J.; Bai, J.G.; Liang, Y.X. (2006). Optimization of multienzyme production by two mixed strains in solid-state fermentation. Appl. Microbiol. Biotechnol., 73(3), 533-540. 